\title{
The Effect of Safe Ride Programs on Neighborhood Crime
}

\author{
Robert M. Longwell-Grice \\ University of Wisconsin Milwaukee
}

\author{
Amy Carlisle Siever \\ Ball State University
}

\begin{abstract}
Many colleges/universities offer night-time shuttles for their students to promote safety. These services are primarily intended to reduce the likelihood that students will drive after drinking and/or fall victim to crime. To date little data exists validating whether or not shuttle services achieve their goal of keeping students safe. This paper demonstrates that shuttle services do in fact reduce student victimization in the areas they serve by reducing the overall crime rate in these same areas. The study has relevance for other campus' currently sponsoring, or considering sponsoring, such services.
\end{abstract}

\section{INTRODUCTION}

Private expenditures on crime deterrence and prevention are enormous. In the United States, more funds are spent for private security than for police (U.S. Census Bureau, 2012). Private efforts to reduce crime include block watches, alert systems, security equipment, and personal expenditures on selfdefense. Colleges and universities are similarly concerned about the safety of their students, and spend a great deal of time and money on programs related to the safety of their students. These programs include, but are not limited to foot patrols, nighttime escort services, better lighting, and self-defense courses. They also include van service or 'safe ride' programs for students. All of these programs and services are designed to keep students safe. But is it possible that these programs, in particular the safe ride programs, serve a secondary purpose: reducing the crime rate in the neighborhoods surrounding the campus? This paper looks at the effect that one safe ride program had on the crime rate in the neighborhoods served, and determined that the van service did indeed reduce the crime rate in the area served. The results will be useful for students and administrators who can use the data to make a strong case that safe ride programs not only prevent students from becoming victims, they also have a wide-ranging, positive affect on the campus community they serve.

\section{Purpose of Safe Ride Programs}

According to the National Center for Educational Statistics (NCES), 34\% of public four-year universities, and $24 \%$ of private four-year universities have some version of a safe ride program. These programs vary in their hours and breadth of services, but they were all designed for two purposes: 1) prevent the victimization of students and; 2) prevent students from driving drunk (Lewis, 1997). Although there are no specific organizations that keep track of all the campus safe ride programs, two 
national organizations do exist to help students develop and maintain them. These organizations are Safe Ride Programs United (SRPU) and the BACCHUS Initiative (part of NASPA: The National Association of Student Personnel Administrators). When one scans their respective websites, it is clear to see that the foci of these programs are, indeed, safety of the students and prevention of drunk driving. According to Gieck and Slagle (2010), students using safe ride programs do, in fact, use them for these two reasons. Additionally, Gieck and Slagle found in their study that $75 \%$ of students using the safe ride program in their study indicated their primary reason for utilizing the safe ride program was to avoid drunken driving. Nineteen percent indicated that a lack of transportation was the reason for their using the service, $16 \%$ used it due to inclement weather, and 34\% used it because their friends did. Although these two foci (safety of students and preventing drunk driving) do exist, this paper focuses on the affect safe ride programs have on student victimization and what affect the one particular program had on the level of crime in the neighborhood it serves.

Colleges and universities have become increasingly concerned about protecting their students since the Jeanne Clery Act took effect in 1991. As a result of this legislation, universities have been required to collect and release crime data for their campuses. These crime data can be instrumental in the enrollment decisions of prospective students and their parents. According to Janosik and Gehring (2003) 60\% of students read crime-related reports, news articles, or flyers produced by their institutions. Their concern about campus crime may be warranted, given the fact that $15 \%$ of the students in this same study reported that they had been a crime victim while they were a student. Colleges, realizing that high crime rates can handicap efforts to attract students (and faculty), to their respective campuses, often use safe ride programs to show how they are actively working to keep their students from becoming victims of crime.

Despite widespread prevalence of these safe ride programs, however, little systematic exploration has been done to assess their effectiveness. While Elam, McKaig, Jacobs, Whitlow and Louis (2006) found that a majority of students believe that safe ride programs are effective, there exists no statistical analysis of the actual effectiveness of safe ride programs on campus. Given the substantial investment that colleges continue to make with these programs and the increasing pressure on programs to demonstrate that they are having an impact, such studies could have a substantial impact for these programs in terms of funding and improving town/gown relationships.

\section{History of Horsehead's Safe Ride Program}

In 1999 the University of Horseheads, started an evening shuttle program, Safe Side (SS), for students to utilize on campus and in the surrounding neighborhood. At its inception the program was defined as being a core component of UH's commitment to campus safety. When SS started in 1999, neighborhood patrol teams were also part of the program and that practice continues today. During SS operation hours, three teams of two continue to walk the neighborhood surrounding the campus. If a student calls SS for a ride and needs to travel less than three blocks, the patrol team walks with the student instead of providing a shuttle. In this way the patrol program works to alleviate the burden SS faces during its busiest times, while still providing an escort service many students want to ensure their safety.

The SS program has some rules to guide its operation, but many of its policies are intentionally vague. This way students can take unlimited rides during the year, and the service is not limited by the location they will travel. While the geographic territory is defined, places within the territory are generally not restricted.

Shuttle programs such as SS help protect students by providing them with a safe method of transportation home during evening hours. According to DeJong (1995) these programs also serve as a formal reminder to students that there is no need to drive under the influence. The service discourages drunk driving by providing students an alternative way to get home safely. Gieck and Slagle (2006) claim that safe ride programs provide substantial cost benefits to the community as well. Using data from the National Highway Transportation and Safety Administration, Gieck and Slagle calculate that for every $\$ 1$ spent on safe ride programs, the community served saves $\$ 3$ on drunk-driving related costs such as medical expenses, property damage, legal fees and quality of life losses. In another study examining a late night bus study, police captains stated their appreciation for such services because they felt it kept intoxicated people from driving or walking home, which in turn resulted in fewer alcohol-related arrests 
(Elam, McKaig, Jacobs, Whitlow, Gros Louis, 2006). Although these programs can sometimes be seen as expensive for the college they serve, there is also a clear, demonstrable benefit for the campus community.

Even though there has been general support to continue shuttle programs on campus, there have been some negative responses to these services as well. Critics of these programs wonder if they actually encourage alcohol consumption by providing a ride home (DeJong, 1995). If a student is guaranteed a free ride home at the end of the night, it enables them to drink to the point of intoxication, the criticism goes. Since alcohol use/abuse is a chronic problem on campus, why should campuses fund a program that encourages rather than discourages such behavior, the argument goes. Additionally, there are concerns that these programs are not actually making any long-term impact on reducing crime. In Kelly and Torres's study of women's perceptions of campus safety, they stated that safety services are crucial to the campus, but "these measures only address the fear of crime" (Kelly \& Torres, 2006). Those who express concerns about these programs are concerned with sending students the wrong message and wish to make a larger impact on crime on and near the campus.

When parents are getting ready to send their sons and daughters off to college, questions about campus safety often arise during the school selection process. In Janosik's (2004) study on "Parents' Views on the Clery Act and Campus Safety," he found that parents often ask questions related to campus safety and criminal activity during campus visits and new student orientation. This same study found, however, that crime statistics do not factor into the college decision for parents. This could simply mean that parents, while interested in what colleges and universities are doing to keep their students safe, do not have safety as a priority when selecting a school for their child.

Although different universities implement campus shuttle programs at different capacities, these services are becoming a necessity for all the reasons discussed here. And, even though this might be seen as a short term solution to the problem of crime in the campus community, nonetheless shuttle services do promote a feeling that the campus is safe and the school cares about student safety.

\section{Methodology}

The data for this study was collected from the Safe Side (SS) program itself, as well as the Horsehead's Police Department (HPD). SS is operated by the Student Affairs Division at the UH. The University of Horseheads is located on the upper east side of Horseheads and, at the time of this study, had approximately 30,000 students. About $1 / 3$ of the undergraduate student population lives on or near the campus and many of these students use the SS service at some point in their college career. The data for the study was from 2005 through 2008. During that time SS offered an average of 133,733 rides per year. Operating hours and related data were collected from January 1, 2005 through June 30, 2008. Data about crime was collected from the Horseheads Police Department through their on-line system COMPASS. This system identifies when the crime occurs, where the crime occurs, and the type of crime that has occurred. Using geographic information systems (GIS) software, the data was trimmed to match the local area that SS serves.

In conducting a study related to campus shuttles and safety, one can see university policy makers keep the program open when crime tends to occur. This leads to concerns with reverse causality. When this occurs, positive correlation can be expected between the hours the program is open and the count of the crime. Indeed, relatively little crime occurs between $2 \mathrm{am}$ and noon. Additionally, the night hours before 2 am have more crime than daylight hours (Dudzinski, 2011). More crime occurs at night than during the day. Therefore, to control for this reverse causality, each hour of the week is given unique propensity for crime over the data window and is supported by the frequency of the programs opening and closing. Comparing the pooled and fixed effect estimates helps isolate this confounding effect.

Additionally, variations in the provision of the program acts as quasi-natural experiment to identify its impact on crime. Poisson regression is required for an hourly number of crime as a count data. Therefore, the following regression is created:

$$
\text { crime }_{i t}=e^{\left(\text {open }_{i t} * \delta_{1}+x_{i t} * \beta\right)}+\epsilon_{i t}
$$


Where the independent variables, $i$ and $t$, represent the hour of $i$ from the week $t$ in the 182 weeks of the time frame. The variable of interest, open ${ }_{i t}$, is given the value of 1 if the SS van service is open that hour, otherwise 0 . The coefficient $\delta_{1}$ denotes the relationship between the SS van program being open and crime. $x_{i t}$ is the pooled content of control vector, varying with specific estimate. The coefficients are interpretable as the response in the percentage of hourly crimes from a unit of increase in the independent variable. Also, to avoid overdispersion from Poisson data, the coefficients are bootstrapped 200 times following the recommendation from Efrom and Tibshirani (1993).

\section{FINDINGS}

To generate the $x_{i t}$ containing the best information of controlled condition, so as to uncover the effect of the SS van program as accurately, multiple specifications were attempted.The result is shown in Table 1.

TABLE 1

COEFFICIENT AND SIGNIFICANCE OF THE EFFECT OF EACH ELEMENT ON CRIME

\begin{tabular}{|c|c|c|c|c|c|c|c|c|}
\hline & 1 & 2 & 3 & 4 & $\begin{array}{c}5 \\
\text { week } \\
\text { days }\end{array}$ & $\begin{array}{c}6 \\
\text { week } \\
\text { ends }\end{array}$ & $\begin{array}{c}7 \\
\text { violent }\end{array}$ & $\begin{array}{c}8 \\
\text { non } \\
\text { violent }\end{array}$ \\
\hline \multirow[t]{2}{*}{ Open } & -0.09102 & -0.08757 & -0.08480 & -0.15179 & -0.20491 & -0.08122 & -0.14608 & -0.18488 \\
\hline & $(1.84)^{*}$ & $(1.74)^{*}$ & $(1.68)^{*}$ & $(3.56)^{* * *}$ & $(4.53)^{* * *}$ & $(1.09)$ & $(3.70)^{* * *}$ & $(2.13)^{* *}$ \\
\hline \multirow[t]{2}{*}{ School } & & 0.16624 & 0.17256 & 0.18292 & 0.13999 & 0.22709 & 0.17782 & 0.21882 \\
\hline & & $(4.49)^{* * *}$ & $(4.63)^{* * *}$ & $(5.35)^{* * *}$ & $(3.05)^{* * *}$ & $(5.20)^{* * *}$ & $(5.61)^{* * *}$ & $(2.33)^{* *}$ \\
\hline \multirow[t]{2}{*}{ Precipitation $(.1 \mathrm{~mm})$} & & & -0.01742 & -0.01860 & 0.00792 & -0.03701 & -0.01209 & -0.06535 \\
\hline & & & $(1.42)$ & $(1.47)$ & $(0.38)$ & $(2.27)^{* *}$ & $(0.96)$ & $(1.96)^{*}$ \\
\hline \multirow[t]{2}{*}{ Snow $(.1 \mathrm{~mm})$} & & & -0.10731 & -0.09934 & -0.23003 & 0.00749 & -0.09583 & -0.12487 \\
\hline & & & $(2.64)^{* * *}$ & $(2.46)^{* *}$ & $(3.29)^{* * *}$ & $(0.11)$ & $(2.21)^{* *}$ & $(0.87)$ \\
\hline \multirow[t]{2}{*}{ Snow down $(\mathrm{mm})$} & & & -0.02491 & -0.02535 & 0.00386 & -0.06017 & -0.03193 & 0.02090 \\
\hline & & & $(1.21)$ & $(1.21)$ & $(0.15)$ & $(1.99)^{* *}$ & $(1.44)$ & $(0.41)$ \\
\hline \multirow[t]{2}{*}{$\operatorname{Min} \operatorname{temp}(.1 \mathrm{C})$} & & & 0.00505 & 0.00437 & 0.0006 & 0.00902 & 0.00415 & 0.00576 \\
\hline & & & $(2.29)^{* *}$ & $(1.96)^{*}$ & $(0.20)$ & $(2.14)^{* *}$ & $(1.93)^{*}$ & $(1.00)$ \\
\hline \multirow[t]{2}{*}{ _constant } & -0.04617 & -0.20954 & -0.01506 & & & & & \\
\hline & $(1.15)$ & $(3.55)^{* * *}$ & $(2.56)^{* *}$ & & & & & \\
\hline $\mathrm{N}$ & 30648 & 30648 & 30648 & 30648 & 17496 & 13152 & 30648 & 30466 \\
\hline
\end{tabular}

$$
\mathrm{P}<0.1 \text { is } *, \mathrm{p}<0.05 \text { is **, } \mathrm{p}<0.01 \text { is } * * *
$$

Column 1 in Table 1 shows the simple partial correlation involving only the element of whether the SS van program is open or not. We can see that the opening of the SS van program is correlated with a weakly significant $9.1 \%$ decline in count of crimes $(b=-0.091, t=1.84, p<0.1)$. 
Column 2 has both SS van program and open school in sessions in the model because one may consider when school is open crime around school as well as the demand for transportation and rides increase. This is supported by the coefficient that effect of school session accounts for $16.6 \%$ of the crime increase in school. By adding this element, the effect of the SS van program drops slightly to $8.8 \%$ in reducing crime counts, which is still significant $(b=-0.088, t=1.74, p<0.1)$.

Column 3 considers the effect of weather since weather impacts both demand for transportation and crime. Meaningful weather conditions may include rain, snow and the temperature. As shown in the column, one unit of increase in precipitation, snowfall and snow on the ground tends to decrease the crime count by $1.7 \%, 10.7 \%$ and $2.5 \%$ respectively; while, if minimum temperature increases by one Celsius degree, crime count will be 5\% higher. With the weather condition considered, the effect of school in session increases to $17.3 \%$. The target effect, the effect of the SS van program, decreases again to even weaker but significant $8.5 \%(b=-0.085, t=1.68, p<0.1)$.

Finally in column 4 we add the effect for hour of the week, meaning the interaction of hour and day, based on the consideration that each hour has a different mean amount of total crime. As is shown in the table, when adding the effect for hour of the week, other elements still affect crime counts in the same direction, only the effect size varies from previous ones. A noticeable $15.2 \%$ of the crime count reduction can be attributed to the SS van program $(b=-0.152, t=3.56, p<.01)$, which is nearly as twice as when the effect for hour of the week is not considered. This discrepancy in the magnitude of the coefficient suggest that using the effect of fixed hour of the day uncovered a substantial portion of the endogeneity that exist in the SS van program.

To further investigate the conditions that will possibly affect the SS van program's effect on crime, next we take weekdays (Monday-Thursday) or weekends (Friday- Sunday) into consideration. The result is also displayed in Table 1.

A glance at the table reveals that in general, all the variables affect the crime count in the same direction as before except for precipitation and snow on the ground in the weekdays. These two changed their coefficient signs, meaning one unit of increase in the either precipitation or snow on the ground will encourage, rather than reduce, the crime in weekdays. This may signal that on weekdays the effect of weather, at least of precipitation and snow on the ground, is random. In other words, crime will happen as it should on weekdays no matter what the precipitation of the day is, and how much snow is on the ground. Based on this interpretation, our target effect, the open or close of the SS van program in a designated hour, attribute to as much as $20.5 \%$ of the crime decrease in weekdays $(b=-0.205, t=4.53$, $\mathrm{p}<.01)$, while on weekends, the effect is only $8.1 \%(\mathrm{~b}=-0.081, \mathrm{t}=1.09, \mathrm{p}>.1)$. This comparison may indicate that the SS van program is not nearly as efficient on weekends in respect to crime reduction.

In the last two columns, effect on different types of crime is also presented. When the crimes are categorized into violent and nonviolent based on the XYZ classification system, the SS van program has a significant effect on both of them. In addition, we should notice that, even though both are significant at certain statistical level, the program is more effective on nonviolent crimes $(b=-0.185, t=2.13, p<.05)$ than on violent crimes $(b=-0.146, t=3.70, p<.01)$ : Nonviolent crimes are reduced by $18 \%$ and violent crimes by $15 \%$. The program's effect on nonviolence is probably due to the fact that nonviolent crimes are not necessarily conducted during the night and early morning, when the SS van program operates. Its effect coefficient might be inflated. On the other hand, because the rides are available only when the violent crimes are highly possible, the effect coefficient on violence shown above might be conservative.

Table 2 shows the effect the SS van program has on 4 specific types of crime: Burglary, kidnapping, motor vehicle theft and robbery. While we investigated the number of rides the SS vans give in an hour, several relationships between crime and the SS van program were uncovered. Within the 35 crime categories that we examined, all of them received negative effect implications with only one notable exception: Kidnapping. This means, for the 34 crime categories, additional rides lower every single crime category if the impact is significant. If the impact is not significant, additional rides may still reduce crime in that category, but the effect is not statistically significant. The significant effect details of the SS van program on the 4 categories of crimes are presented in Table 2 below. 
TABLE 2

COEFFICIENT AND SIGNIFICANCE OF EACH ELEMENT ON 4 SPECIFIC TYPES OF CRIME

\begin{tabular}{|c|c|c|c|c|}
\hline & $\begin{array}{c}1 \\
\text { Burglary }\end{array}$ & $\begin{array}{c}2 \\
\text { Kidnapping }\end{array}$ & $\begin{array}{c}3 \\
\text { MV theft }\end{array}$ & $\begin{array}{c}4 \\
\text { Robbery }\end{array}$ \\
\hline Rides (hourly) & $\begin{array}{l}-0.006699 \\
(3.04)^{* * *}\end{array}$ & $\begin{array}{l}0.06989 \\
(2.19)^{* *}\end{array}$ & $\begin{array}{c}-0.003373 \\
(1.90)^{*}\end{array}$ & $\begin{array}{c}-0.003429 \\
(1.81)^{*}\end{array}$ \\
\hline Snow (.1mm) & $\begin{array}{c}-0.001070 \\
(0.68)\end{array}$ & $\begin{array}{c}0.003388 \\
(0.29)\end{array}$ & $\begin{array}{c}-0.002172 \\
(1.78)^{*}\end{array}$ & $\begin{array}{c}-0.0008038 \\
(0.37)\end{array}$ \\
\hline Snow down $(\mathrm{mm})$ & $\begin{array}{c}-0.000848 \\
(1.17)\end{array}$ & $\begin{array}{c}-0.004522 \\
(0.64)\end{array}$ & $\begin{array}{c}-0.0008746 \\
(1.62)\end{array}$ & $\begin{array}{c}0.0006774 \\
(0.71)\end{array}$ \\
\hline $\operatorname{Min}$ temp(.1C) & $\begin{array}{c}0.0000605 \\
(0.09)\end{array}$ & $\begin{array}{c}0.01169 \\
(1.57)\end{array}$ & $\begin{array}{c}-0.0003 .88 \\
(0.72)\end{array}$ & $\begin{array}{c}0.001378 \\
(1.44)\end{array}$ \\
\hline $\begin{array}{l}\text { Precipitation } \\
(.1 \mathrm{~mm})\end{array}$ & 0.0003108 & $\begin{array}{c}0.0003668 \\
(0.09)\end{array}$ & 0.0002171 & $\begin{array}{c}-0.001 .008 \\
(1.53)\end{array}$ \\
\hline Monday & $\begin{array}{c}0.07493 \\
(0.63)\end{array}$ & $\begin{array}{l}-2.071 \\
(1.53)\end{array}$ & $\begin{array}{c}0.07511 \\
(0.84)\end{array}$ & $\begin{array}{c}-0.1245 \\
(0.81)\end{array}$ \\
\hline Friday & $\begin{array}{c}0.08 .136 \\
(0.68)\end{array}$ & $\begin{array}{l}-1.784 \\
(1.36)\end{array}$ & $\begin{array}{c}-0.01480 \\
(1.61)\end{array}$ & $\begin{array}{c}0.06313 \\
(0.42)\end{array}$ \\
\hline $2 \mathrm{am}$ & $\begin{array}{c}-0.2742 \\
(1.13)\end{array}$ & $\begin{array}{l}-28.38 \\
(0.00)\end{array}$ & $\begin{array}{c}0.09131 \\
(0.48)\end{array}$ & $\begin{array}{c}-0.1215 \\
(0.49)\end{array}$ \\
\hline 9am & $\begin{array}{c}0.5 .994 \\
(2.59)^{* * *}\end{array}$ & $\begin{array}{l}3.782 \\
(1.40)\end{array}$ & $\begin{array}{l}0.5777 \\
(3.01)\end{array}$ & $\begin{array}{c}-2.457 \\
(6.83)^{* * *}\end{array}$ \\
\hline Noon & $\begin{array}{l}0.4374 \\
(1.87)^{*}\end{array}$ & $\begin{array}{l}1.806 \\
(0.60)\end{array}$ & $\begin{array}{c}0.7936 \\
(4.20)^{* * *}\end{array}$ & $\begin{array}{c}-3.340 \\
(4.47)^{* * *}\end{array}$ \\
\hline June & $\begin{array}{c}0.5646 \\
(2.78)^{* * *}\end{array}$ & $\begin{array}{l}-3.814 \\
(1.82)^{*}\end{array}$ & $\begin{array}{l}-0.2734 \\
(1.73)^{*}\end{array}$ & $\begin{array}{c}0.04864 \\
(0.17)\end{array}$ \\
\hline 2007 & $\begin{array}{c}0.4055 \\
(4.97)^{* * *}\end{array}$ & $\begin{array}{c}-0.5513 \\
(0.55)\end{array}$ & $\begin{array}{c}0.2630 \\
(4.04)^{* * *}\end{array}$ & $\begin{array}{l}0.1661 \\
(1.50)\end{array}$ \\
\hline Constant & $\begin{array}{c}-5.135 \\
(19.74)^{* * *}\end{array}$ & $\begin{array}{c}-20.80 \\
(5.19)^{* * *}\end{array}$ & $\begin{array}{c}-3.632 \\
(17.87)^{* * *}\end{array}$ & $\begin{array}{c}-4.768 \\
(15.46)^{* * *}\end{array}$ \\
\hline $\mathrm{N}$ & 30648 & 30648 & 30648 & 30648 \\
\hline
\end{tabular}

The elements of control listed in Table 2 are presented here. To study the hourly rides as its relationship to each of the crime categories, the total slate of controls has been contained in the table, including an indicator for every hour of the day, every day of the week, every month of the year and every year as well as the set of weather variables. However, uninteresting controls are omitted for brevity, keeping only the weather variables, Monday, Friday, 2am, 9am, noon and June as reference. These are selected because of the anecdotal values of Monday and Friday nights as "low crime" and "high crime" respectively. June was chosen to represent summer break. The times of $2 \mathrm{am}, 9 \mathrm{am}$ and noon were chosen to represent bar close, typical work hours and lunch time, respectively. The constant term represent a "normal time", which the results are centered around, the time of Sunday at 12am in January, 2005.

In spite of the small coefficient value due to the measuring scale of number of rides, we can see that an additional ride from an SS van will reduce about burglary by about $7 \%(b=-0.0069, t=3.04, p<.01)$, motor vehicle theft by about $3 \%(b=-0.0034, t=1.90, p<.1)$ and robbery by about $3 \%(b=-0.0034, t=1.81$, $\mathrm{p}<.1$ ), but encourage kidnapping $(\mathrm{b}=0.070, \mathrm{t}=2.19, \mathrm{p}<.05)$ by $6 \%$. A more visible description of the effect can be found in Table 3 . 


\section{TABLE 3}

\section{A COMPARISON BETWEEN THE EFFECTS OF THE SS VAN PROGRAM AND THE}

SNOWFALL

\begin{tabular}{l|l|l}
\hline crime & Yearly Estimated Impact & The same impact of one ride \\
\hline Burglary & -56 crimes & as $0.7 \mathrm{~mm}$ of snowfall \\
Kidnapping $\dagger$ & +9 crimes & - \\
Motor Vehicle Theft & -38 crimes & as $0.15 \mathrm{~mm}$ of snowfall \\
Robbery $\dagger$ & -39 crimes & as $0.4 \mathrm{~mm}$ of snowfall \\
\hline Aggregated Violent Crime $\dagger$ & -68 crimes & as $0.5 \mathrm{~mm}$ of snowfall \\
Aggregated Nonviolent Crime & -216 crimes & as $0.1 \mathrm{~mm}$ of snowfall \\
\hline
\end{tabular}

Note: SS delivers about 133,000 rides yearly. $\dagger$ is categorized as a violent crime.

While the table has coefficient of elements on each crime type with a sign indicating it is promoting or reducing the type of crime, there are two additional patterns of notes in the data. First, burglaries begin during the day, and tend to stop in the evening. In general, burglaries are likely to happen when people go to work (represented as 9am in Table 2), and not when they come home. Burglaries are unlikely to occur in the evening. Secondly, agreeing with the discussion above for Weekdays, weather element such as snow, snow on the ground, minimum temperature and precipitation do not dampen violent crimes. Most of these crimes appear to be impulsive, and therefore not particularly responsive to weather. Nonviolent crimes, such as vandalism and larceny, are very likely to be premeditated, and therefore impacted somehow by the weather.

While the program's impact on other crime categories are not significant, a list of all the crimes categories that are studied in this research appears in the appendix to illustrate the statistically insignificant but practically important impact a shuttle program can have potentially. Although these crime categories were not affected in this study, it is entirely reasonable to think that a similar shuttle service operating somewhere else could have a positive affect in reducing crime in some of these categories. As the results are clear and confident, it is reasonable to conclude from all the discussion above that SS van program reduces crime in a measurable and statistically significant amount.

\section{DISCUSSION}

Given the amount of money spent yearly on van shuttle and escort services on campuses across the country, these data will provide excellent justification to continue funding and, in some cases, enhancing these programs. The data from this study confirm what many administrators feel, and what some researchers have anecdotally found. Elam, McKaig, Jacobs, Whitlow, and Louis (2006), for example, stated "While one purported benefit of the Midnight Special (a Safe Ride program at one university in the Midwest) is keeping intoxicated student drivers off the road, available police arrest data are largely inconclusive, if not contradictory, to this claim. However, this perception remains, along with contentions that vandalism, noise, fights, and other alcohol-related disturbances have also been reduced by this service." They go on to suggest "Efforts should be made by university administrators to work with the police departments to gather outcomes data more formally that can validly establish or refute these claims."

Similarly Ketterman and Holmes (2009), in their analysis of the Safe Ride program at Frostburg State University, found that while the program was initially established to provide students with safe rides home at night, "Soon after implementation, the campus learned of other benefits of the program. The local law enforcement agency indicated that there was a decrease in nighttime vandalism. The local neighborhood group reported that nighttime noise also had decreased."

While data from the study by Gieck and Slagle (2006) found that passengers using safe ride programs do so in order to reduce the risk of harm to themselves and others, there is also a monetary reason for colleges and universities to establish Safe Ride programs for their students. According to the National 
Highway Traffic Safety Administration (2002), safe ride programs save their communities $\$ 3$ for every $\$ 1$ spent on these programs.

Despite their effectiveness, however, Safe Ride programs can still use some good PR. In their study assessing late night bus services, Geick and Stangle found that $60 \%$ of students felt that safe ride programs promote drinking. Since safe ride programs do carry students to and from bars, it is entirely possible that community members might also feel these programs encourage students to drink. Nineteen percent of the students in Geick and Stangle's study said that when they used the Safe Ride program, they did consume more alcohol because the ride was available, however, $81 \%$ of these same students claimed that using the service did not influence their drinking behavior. These statistics certainly can be used to combat these criticisms.

There is an inherent conflict that does occur with college shuttle services operating at night. If the vans are operating for the purpose of safety, then it is reasonable to expect students would be given rides when they are intoxicated. Students walking home from bars and parties are often the victim of crime and providing them with rides reduces the chance they will be victimized. Additionally, students who are intoxicated often behave in ways they would not when they are sober. Although this study shows that the SS van service did reduce crime in the neighborhoods it serves, it does not address the issue of whether these crimes were committed by students or enacted towards students. Taking intoxicated students off the streets reduces the chances of either situation happening. One of the SS programs policies states that vans 'will not pick up from a location that is suspected of inappropriate behavior'. While this is commendable, and most likely done to protect the drivers and passengers, it also raises an interesting question: Isn't one of the purposes of the shuttle to prevent inappropriate behavior? If a student was at a party and the party was getting out of hand, the shuttle service could be very helpful. The authors also want to acknowledge that this study was conducted with traditional age students since those are the students who generally use the SS van service. There may be other services that benefit adult students from a crime prevention standpoint, but most van shuttles target traditional aged students since these are the students who generally live on campus, and within a short radius of campus.

As mentioned earlier in this paper, expenditures on crime deterrence and prevention continue to rise as colleges and universities, concerned about the safety of their students expend large amounts of time and money on programs related to the safety of their students. All of these programs and services are designed to keep students safe but there so far has been little documented proof that safe ride programs do, indeed, reduce crime and help keep students safe.This paper looked at the effect one safe ride program had on the crime rate in the neighborhoods served, and determined that the van service did indeed reduce the crime rate in the area served. Further studies are in order to support the findings of this study.

We recommend that other urban campuses do similar studies to determine if similar reductions are caused based on other types of safe ride programs. We also would recommend that a study be undertaken to determine the amount of money communities save as a result of this reduction in crime. Finally, related to the issue of drunk driving, we would recommend a study be set up to determine how many accidents are avoided due to these safe ride programs, and how much money is saved as a result. Taken together, the results of these studies would provide indisputable proof of the necessity of these programs. As it is, the results of the study in this paper will be useful for students and administrators who can use the data to make a strong case that safe ride programs have a wide-ranging, positive affect on their college and their community. 


\section{REFERENCES}

BACCHUS Initiative. (n.d.). The National Association of Student Personnel Administrators (NASPA). Retrieved from https://www.naspa.org/constituent-groups/groups/bacchus-initiatives

DeJong, W. (1995). Preventing alcohol-related problems on campus: Impaired driving: A guide for program coordinators. Bethesda, Md.?: Higher Education Center for Alcohol and Other Drug Prevention. pg. 33-37

Dudzinski, D.G. (2011). Assessing the relationship of crime to the time of day and human factors (Doctoral dissertation). Retrieved from Dissertation Abstracts International, A: The Humanities and, Social Sciences.

Efrom, B. \& R. Tibshirani. (1993). An introduction to the bootstrap. New York: Chapman \& Hall.

Elam, C., McKaig, R. N., Jacobs, B., Whitlow, M., Gros Louis, K. R. (2006). Examining a Safe Ride Program: An Assessment of the Midnight Special Late Night Bus Service. NASPA Journal, (43) 2, 358-376.

Gieck, D. J., \& Slagle, D. M. (2010). Examination of a University - Affiliated Safe Ride Program. Journal of Alcohol and Drug Education, 54(1), 37-55.

Janosik, S. M. (2004). Parents' Views on the Clery Act and Campus Safety. Journal of College Student Development, 45(1), 43-56. Retrieved from Project Muse.

Janosik, Steven M., \& Gehring, Donald D. (2003). The Impact of the Clery Campus Crime Disclosure Act on Student Behavior. Journal of College Student Development, 44(1). 81-91.

Kelly, B. T., \& Torres, A. (2006). Campus Safety: Perceptions and Experiences of Women Students. Journal of College Student Development, 47(1), 20-36. Retrieved from Project Muse.

Ketterman, Jesse M., \& Holmes, Heather. (2009), Saferide: A strategy to address high-risk behaviors associated with alcohol, Student Affairs Leader, 37(19), 4-5.

Lewis, L. (1997). Campus crime and security at postsecondary education institutions. Washington, D.C.: Office of Educational Research and Improvement, Educational Resources Information Center: National Center for Education Statistics.

National Highway Traffic and Safety Administration (2002). Retrieved from nhtsa.gov Safe Ride Programs United (SRPU). (n.d.). Retrieved from http://uasrpu2016.wixsite.com/srpu

University of Horseheads (2016). How to Use SSSS. Retrieved from http://uh.edu/ss/howtouse/.

University of Horseheads (1999). Safe Side Expansion Act.

U.S. Census Bureau. (2012). Retrieved from census.gov 


\section{APPENDIX ONE: SUMMARY OF CRIME DATA}

\begin{tabular}{|l|l|}
\hline Crime Category & Number of Crimes Reported \\
\hline Aggravated assault & 1488 \\
\hline All other larceny & 3815 \\
\hline All other offenses & 97 \\
\hline Arson & 82 \\
\hline Burglary & 2730 \\
\hline Counterfeiting/Forgery & 4 \\
\hline Credit card/ATM fraud & 9 \\
\hline Destruction of property & 5018 \\
\hline Disorderly conduct & 262 \\
\hline Extortion/Blackmail & 0 \\
\hline False pretenses/Swindle/Confidence game & 1 \\
\hline Forcible fondling & 97 \\
\hline Forcible rape & 75 \\
\hline Forcible sodomy & 53 \\
\hline Homicide & 28 \\
\hline Impersonation & 4 \\
\hline incest & 1 \\
\hline Intimidation & 29 \\
\hline Kidnapping & 100 \\
\hline Liquor law violations & 20 \\
\hline Motor vehicle theft & 2493 \\
\hline Pocket picking & 51 \\
\hline Purse snatching & 110 \\
\hline Robbery & 1788 \\
\hline Sexual assault with an object & 15 \\
\hline Shoplifting & 333 \\
\hline Simple assault & 1912 \\
\hline Statutory rape & 45 \\
\hline Stolen property offenses & 8 \\
\hline Theft from building & 198 \\
\hline Theft from coin-operated machine & 33 \\
\hline Theft from motor vehicle & 5655 \\
\hline Theft of motor vehicle parts & 1951 \\
\hline Trespassing & 66 \\
\hline Weapon law violations & 0 \\
\hline & \\
\hline
\end{tabular}

